\title{
THE EFFECT OF WOOD SUPPLY AND BLEACHING PROCESS ON PULP BRIGHTNESS STABILITY ${ }^{1}$
}

\author{
Romildo Lopes Oliveira ${ }^{2}$, Jorge Luiz Colodette ${ }^{3}$, Kátia Maria Morais Eiras ${ }^{2}$ and Gustavo Ventorim ${ }^{2}$
}

\begin{abstract}
One hundred different 5.5-year-old Eucalyptus grandis $x$ Eucalyptus urophylla wood clones were cooked to kappa number 15-17.5 and the resulting kraft pulps oxygen-delignified to kappa 9.5-11.5 under fixed conditions, except for chemical charges. Thirteen samples showing large variations in effective alkali requirement, pulp yield and $\mathrm{O}$-stage efficiency and selectivity were selected for brightness reversion studies. These samples were bleached to 90-91\% ISO by DEDD and DEDP sequences and their brightness stability and chemical characteristics determined. Heat reversion of the eucalyptus kraft pulps was strongly influenced by the wood supply, with brightness loss varying in the range of 2.1-3.6 and 0.8-1.7 \%ISO for ODEDD and ODEDP bleached pulps, respectively. Pulps bleached by the ODEDP sequence showed reversion values 1.3$1.9 \%$ ISO lower than those bleached by the ODEDD sequence. Pulp carbonyl content decreased by $35-40 \%$ during the final peroxide bleaching stage. Carbonyl and carboxyl groups correlated positively with brightness reversion, as did permanganate number and acid soluble lignin. Pulp final viscosity and metal and DCM extractives contents showed no significant correlation with brightness reversion. Pulping, oxygen delignification and ECF bleaching performances also showed no correlation with brightness reversion.
\end{abstract}

Keywords: Wood type; Clones; Bleaching ECF; Bleachability; Brightness reversion.

\section{O EFEITO DO TIPO DE MADEIRA E DO PROCESSO DE BRANQUEAMENTO NA ESTABILIDADE DA ALVURA DA POLPA}

\begin{abstract}
RESUMO - Madeiras de 100 diferentes clones de Eucalyptus grandis e Eucalyptus urophylla, com aproximadamente 5,5 anos de idade, foram cozidas ao número kappa 15-17,5. As polpas kraft produzidas foram pré-deslignificadas com oxigênio ao número kappa 9,5-11,5, sob condições fixas. Treze polpas, que mostraram grandes variações na exigência da carga de álcali efetivo e rendimento no processo de polpação, seletividade e eficiência no estágio de Pré-O, foram selecionadas e branqueadas à alvura DE 90-91\% ISO pelas seqüências DEDD $e$ DEDP, para estudos de estabilidade de alvura e características químicas. A reversão de alvura da polpa branqueada foi fortemente influenciada pelo tipo de madeira, e a perda na alvura variou de 2 - 3,5 e 1 - 2\% ISO para as polpas branqueadas pelas seqüencias ODEDD e ODEDP, respectivamente. Já aquelas branqueadas pela seqüência contendo P-final apresentaram cerca de 35-40\% de redução no conteúdo de grupos carbonila. A análise dos resultados evidenciou uma positiva correlação entre o conteúdo de grupos carbonila e carboxila na polpa branqueada e a estabilidade da alvura, bem como o número de permanganato e o conteúdo de lignina solúvel. A viscosidade final, o teor de metais e de extrativos em DCM da polpa não mostrou correlação significativa com a reversão de alvura. Finalmente, os processos de polpação, deslignificação com oxigênio, e o desempenho branqueamento por seqüências ECF também não mostraram correlação com a reversão de alvura.
\end{abstract}

Palavras-chave: Tipo de madeira; Clones; Branqueamento ECF; Branqueabilidade; Reversão de alvura.

\footnotetext{
${ }^{1}$ Recebido em 19.03.2003 e aceito para publicação em 05.04.2006.

${ }^{2}$ Programa de Pós-Graduação em Ciência Florestal da Universidade Federal de Viçosa. E-mail: <romildo@ cetind.fieb.org.br>.

${ }^{3}$ Departamento de Engenharia Florestal da Universidade Federal de Viçosa.
} 


\section{INTRODUCTION}

Brightness reversion is becoming a very significant issue for Brazilian pulp mills producing fully bleached market kraft pulp from eucalyptus, particularly those manufacturing high brightness (90-91\% ISO) ECF pulps.

Pulp brightness reversion is triggered by light and/or heat during transportation, storage and use. Heat induced reversion is the most significant for bleached chemical pulps because they are subjected to long-term storage (HEITNER 1996; FORSSKÅLL 2000). The heat reversion phenomenon is not very well established for chemical pulps even though the main environmental and chemical factors affecting reversion are already known. Environmental aspects to be considered are relative humidity, temperature, UV light, oxygen, etc. whereas pulp chemical aspects include traces of residual lignin, extractives, transition metals, carboxyl groups (including hexenuronic acids), carbonyl groups, $\mathrm{pH}$, etc.

Conversion from standard to ECF bleaching and the need for very high brightness market pulps have aggravated reversion problems. Chemistry of high brightness standard and ECF bleached pulps may differ slightly, particularly with regard to extractives, metals, carbonyl and carboxyl groups and residual lignin contents but such differences should be sufficiently small so as not to cause large reversion differences. It is apparent that other factors are involved in the brightness reversion problem related to high brightness ECF bleached eucalyptus kraft pulps.

Wood species, tree growing region, pulping and bleaching technologies have all been reported to affect pulp brightness stability (HEITNER 1996; FORSSKÅHL, 2000). Although most Brazilian pulp production comes from eucalyptus clones, wood quality variations among the various clones and within clones are still quite significant. Furthermore, wood scarcity has forced Brazilian pulp mills to use wood from very different regions. Pulping and bleaching technologies within mills are somewhat constant but operational conditions may change on a day-to-day basis.

The purpose of this work was thus to determine the impact of eucalyptus wood supply, pulping, oxygen delignification, bleaching (ODEDD and ODEDP) and pulp chemistry on brightness reversion.

R. Árvore, Viçosa-MG, v.30, n.3, p.439-450, 2006

\section{EXPERIMENTAL}

Pulping and bleaching. One hundred wood samples of different 5.5-year-old Eucalyptus grandis $x$ Eucalyptus urophylla clones were cooked to kappa number $15-17.5$ by the kraft process and the effective alkali requirement and yield were measured. Cooking was carried out with two repetitions under constant conditions $\left(1000 \mathrm{~g}\right.$ chips, $165^{\circ} \mathrm{C}, 90 \mathrm{~min}$ time at temperature, $50 \mathrm{~min}$ time at temperature, $25 \%$ sulfidity, 4/1 liquor/wood ratio), except for the effective alkali, that was varied in order to achieve the kappa target for the different samples. Three hundred gram pulp samples were oxygen delignified (O-stage) in duplicate in a Mark V mixer/reactor (Quantum Technologies) under the conditions shown in Table 1 . Thirteen pulps were chosen within the universe of the one hundred samples produced. The criteria for selection were large variations in effective alkali requirement to achieve the kappa target, brown pulp yield and viscosity, oxygen delignification efficiency and selectivity, and brightness gain across the O-stage. Efficiency and selectivity of the $\mathrm{O}$-stage were determined using the following equations: efficiency: (kappa in - kappa out)/kappa in*100; selectivity: viscosity units drop/kappa units drop across the O-stage. The 13 selected pulp samples were bleached in duplicate by the DEDD and DEDP sequences to a brightness target of 90-91\% ISO and their brightness reversion and chemical characteristics were determined. Conventional bleaching stages (D, $\mathrm{E}$ and $\mathrm{P}$ ) were carried out with $150 \mathrm{~g}$ oven dry samples contained in polyethylene bags. Pulp washing between stages was performed with $9 \mathrm{~m}^{3}$ of water per ton of pulp.

Standardization of the Brightness Reversion Procedure. To understand the problem of brightness reversion it is critical to establish reliable methods of quantifying brightness drop in the aging test. The most commonly used techniques are through the measurements of brightness loss ( $\Delta \mathrm{R}_{457}$ in \% ISO), post color number (PCN) and increase in $b^{*}$ coordinate $\left(\Delta b^{*}\right)$ across aging. Although the best method of expressing reversion is still a matter of debate, in this study reversion is always reported as $\Delta R_{457}$ (\% ISO) values, since only pulps of similar brightness values are compared. Also, good correlation was obtained between $\Delta \mathrm{R}_{457}$ and PCN or $\Delta \mathrm{b}^{*}$ values (Figures 1 and 2 ). There are also many methods of aging the pulp in order to quantify brightness reversion and they vary 
with regard to time, temperature and relative humidity. Except when otherwise stated, the Tappi method UM $200\left(105^{\circ} \mathrm{C}, 4\right.$ hours, $0 \%$ relative humidity $)$ was used in this study. Exposure times longer than the four hours tend to increase reversion as shown in Table 2, but are less practical to execute in the laboratory. Table 2 also shows that the rate of reversion tends to decrease after the first hours of reaction, in agreement with other reports (RAPSON and SPINNER 1979).

Heat reversion. Heat reversion was carried out in a dedicated forced air circulation oven (excess oxygen) on Tappi hand sheets heated for four hours at $105 \pm 3{ }^{\circ} \mathrm{C}$ and $0 \%$ relative humidity (Tappi UM 200), after acclimation for 12 hours at constant temperature $\left(23 \pm 1^{\circ} \mathrm{C}\right)$ and relative humidity $(50 \pm 2 \%)$. Pulp pH was adjusted with $\mathrm{SO}_{2}$ for bleaching sequences ending with a final $\mathrm{P}$ stage and with $\mathrm{Na}_{2} \mathrm{SO}_{3}$ for bleaching sequences ending with a final D-stage. Reversion tests were replicated 10 times.
Pulp analysis. Except where otherwise stated, pulp analyses were performed according to Tappi standard procedures. Pulp metals contents were measured according to the SCAN-CM 38:96 method. Hexenuronic acids were measured according to the HUT method as described by Tenkanen et al. 1999. Acid soluble lignin was measured according to Goldschmid 1971.

Tables 3 and 4 indicate variations among the reversion test results among the five different pulp hand sheets. In a reversion study, it is very significant to determine how many tests are required in order to have a reliable response. Experiments done with 10 repetitions of four different laboratory bleached pulp samples, along with the use of parametric statistics, indicated that 10 repetitions should be sufficient when using the Tappi UM 200 method, regardless of the pulp type (Table 5).

Table 1 - General bleaching conditions applied to the ODEDD and ODEDP sequences Tabela 1 - Condições gerais de branqueamento aplicadas nas seqüências ODEDD e ODEDP

\begin{tabular}{|c|c|c|c|c|c|c|c|c|}
\hline \multirow[t]{2}{*}{ General conditions } & \multicolumn{8}{|c|}{ Bleaching Stage } \\
\hline & $\mathrm{O}$ & $\mathrm{D}$ & E & $(\mathrm{Ze})$ & $\mathrm{D}_{1}$ & $\mathrm{D}_{2}$ & $\mathrm{P}$ & $(\mathrm{PO})$ \\
\hline Consistency, \% & 10 & 10 & 10 & 10 & 10 & 10 & 10 & 10 \\
\hline Temperature, ${ }^{\circ} \mathrm{C}$ & 105 & 60 & 70 & $(\mathrm{Amb} . / 70)$ & 70 & 70 & 90 & 90 \\
\hline Time, min & 40 & 30 & 60 & $(0.5 / 15)$ & 180 & 120 & 120 & 120 \\
\hline Pressure, $\mathrm{kPa}$ & 500 & - & - & - & - & - & - & 400 \\
\hline Final pH & 11.4 & 3.2 & 11.2 & 11.3 & 3.8 & 4.1 & 10.5 & 10.6 \\
\hline $\mathrm{NaOH}, \%$ & 1.8 & - & 1.0 & 0.6 & 0.25 & $0.1-0.5$ & $0.6-0.8$ & $0.6-0.8$ \\
\hline $\mathrm{H}_{2} \mathrm{SO}_{4}, \%$ & - & 8 & - & - & - & - & - & - \\
\hline $\mathrm{O}_{3}^{2}, \%$ & - & - & - & 0.4 & & & & - \\
\hline $\mathrm{O}_{2}, \%$ & 2.0 & $\mathrm{KF}^{1}-020$ & - & - & 5 & $02-04$ & - & 1.8 \\
\hline $\begin{array}{l}\mathrm{ClO}_{2}, \% \text { as } \mathrm{Cl}_{2} \\
\mathrm{H}_{2} \mathrm{O}_{2}, \%\end{array}$ & - & $\begin{aligned} & \mathrm{KF}^{1}=0.20 \\
&-\end{aligned}$ & - & - & $\begin{array}{c}2.0 \\
-\end{array}$ & $\begin{array}{c}0.2-0.4 \\
-\end{array}$ & $0.2-0.4$ & $0.2-0.4$ \\
\hline
\end{tabular}

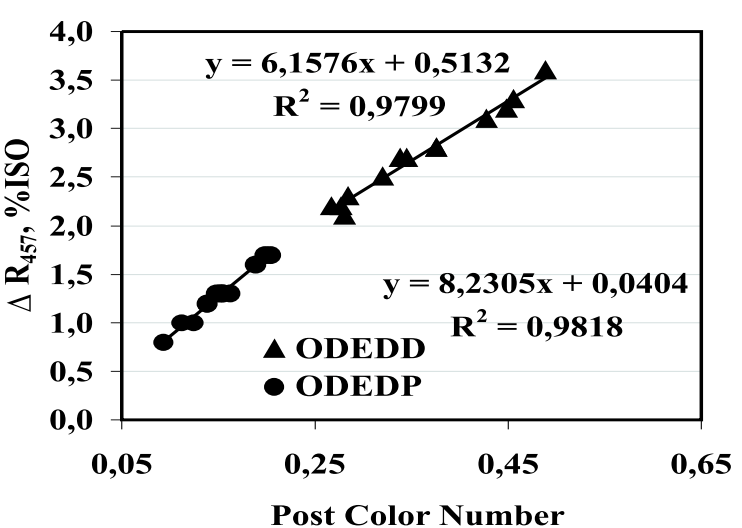

Figure $1-\Delta R_{457} x$ post color number. Figura $1-\Delta R_{457} x$ Número de cor posterior.

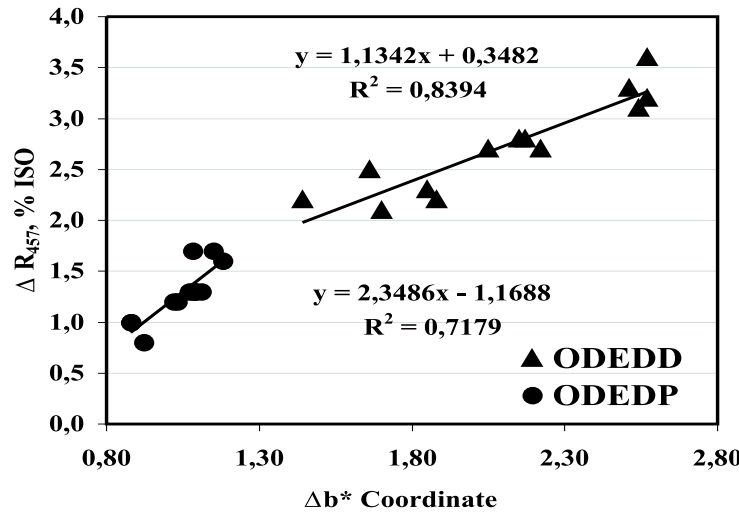

Figure $2-\Delta \mathrm{R}_{457} \times$ Coordenada $\mathrm{Ab}$. Figura $2-\Delta R_{457} x$ Coordenada $A b$.

R. Árvore, Viçosa-MG, v.30, n.3, p.439-450, 2006 
Table 2-Brightness loss $\left(\Delta \mathrm{R}_{457}\right.$ in \% ISO) of three industrial bleached pulp samples (90-91\% ISO, pH 6.0, 91 $\pm 0.5 \%$ dryness) during exposure at $105 \pm 3{ }^{\circ} \mathrm{C}$ and $0 \%$ relative humidity

Tabela 2 - Perda de alvura $\left(\Delta R_{457} \%\right.$ ISO) de três amostras de polpa industrial branqueada (90-91\% ISO, pH 6,0, $91 \pm 0,5 \%$ absolutamente seca) expostas a $105 \pm 3{ }^{\circ} \mathrm{C}$ e $0 \%$ de umidade relativa

\begin{tabular}{lccc}
\hline $\begin{array}{l}\text { Reversion } \\
\text { Time, } \mathrm{h}\end{array}$ & Sample 1 & Sample 2 & Sample 3 \\
\hline 1 & 0,84 & 1,10 & 1,66 \\
4 & 1,18 & 1,60 & 2,61 \\
12 & 1,24 & 2,17 & 3,96 \\
18 & 1,45 & 2,40 & 4,30 \\
24 & 1,87 & 2,65 & 4,76 \\
\hline
\end{tabular}

Table 4 - Brightness loss ( $\Delta \mathrm{R}_{457}$ in \% ISO) of a O(ZE)D(PO) bleached pulp sample of various dryness values $(91.8 \%$ ISO, pH 6.0) during exposure for 4 hours at $105 \pm 3$ ${ }^{\circ} \mathrm{C}$ and $0 \%$ relative humidity

Tabela 4 - Perda de alvura $\left(\Delta R_{457}, \%\right.$ ISO) das amostras de polpa branqueadas pela seqüência $O(Z E) D(P O)$ com variaça no nos valores de umidade da folha (91,8\% ISO, pH 6.0), expostas durante 4 horas a $105 \pm 3{ }^{\circ} \mathrm{C}$ e $0 \%$ de umidade relativa

\begin{tabular}{ccccc}
\hline Hand & \multicolumn{4}{c}{ Hand Sheet Dryness, \% } \\
\cline { 2 - 5 } Sheet \# & 88.5 & 89.0 & 90.1 & 91.0 \\
\hline 1 & 1.60 & 1.61 & 1.42 & 0.98 \\
2 & 1.73 & 1.51 & 1.51 & 0.91 \\
3 & 1.64 & 1.54 & 1.47 & 1.02 \\
4 & 1.59 & 1.59 & 1.50 & 1.02 \\
5 & 1.92 & 1.58 & 1.49 & 0.98 \\
Average & 1.70 & 1.57 & 1.48 & 0.98 \\
\hline
\end{tabular}

Table 3 - Brightness loss ( $\Delta \mathrm{R}_{457}$ in \% ISO) of a O(ZE)D(PO) bleached pulp sample at various $\mathrm{pH}$ values $(91.8 \%$ ISO, $91 \pm 0,5 \%$ dryness) during exposure for 4 hours at $105 \pm 3 \mathrm{C}$ and $0 \%$ relative humidity

Tabela 3 - Perda de alvura $\left(\Delta R_{457}, \%\right.$ ISO $)$ da amostra de polpa branqueada pela seqüência $O(Z E) D(P O)$ com variação no $\mathrm{pH}$ da folha (91,8\% ISO, 910,5\% absolutamente seca) exposta durante 4 horas a $105 \pm 3{ }^{\circ} \mathrm{Ce} 0 \%$ de umidade relativa

\begin{tabular}{lccccccc}
\hline \multirow{2}{*}{$\begin{array}{l}\text { Hand } \\
\text { sheet \# }\end{array}$} & 3.0 & 4.0 & 5.0 & 6.0 & 7.0 & 8.0 & 9.0 \\
\hline & 1.68 & 1.27 & 1.33 & 0.98 & 1.12 & 1.12 & 1.49 \\
2 & 1.50 & 1.36 & 1.35 & 0.91 & 1.07 & 1.21 & 1.48 \\
3 & 1.54 & 1.34 & 1.27 & 1.02 & 1.10 & 1.14 & 1.43 \\
4 & 1.43 & 1.26 & 1.30 & 1.02 & 1.18 & 1.11 & 1.45 \\
5 & 1.47 & 1.28 & 1.22 & 0.98 & 1.09 & 1.12 & 1.41 \\
Average & 1.52 & 1.30 & 1.29 & 0.98 & 1.11 & 1.14 & 1.45 \\
\hline
\end{tabular}

Typical ways to access residual lignin in bleached pulps are through kappa or permanganate number measurements, but these techniques are very general and can also quantify other oxidizable materials present in the pulp. Another way is through direct spectrophotometric measurement of acid soluble lignin in the filtrate after complete hydrolysis of pulp carbohydrates (GOLDSHMID, 1971). If any insoluble lignin is present in the pulp, it is quantified gravimetrically using the Klason method (HOLMBLOM, 2000). In the bleached pulp samples evaluated in this study no acid soluble lignin was found.

Table 5 - Brightness loss $\left(\Delta \mathrm{R}_{457}\right.$ in \% ISO) of four laboratory bleached pulp samples (90-91\% ISO, pH 6,0, 91 $\pm 0,5 \%$ dryness) during exposure for 4 hours at $105 \pm 3{ }^{\circ} \mathrm{C}$ and $0 \%$ relative humidity

Tabela 5 - Perda de alvura $(\triangle R 457, \%$ ISO) de quatro seqüências de branqueamento laboratorial de amostras de polpa 90-91\% ISO, pH 6,0, $91 \pm 0,5 \%$ (absolutamente seca)

\begin{tabular}{ccccc}
\hline Hand Sheet \# & $\begin{array}{c}\text { O(DC)(EOP)DD } \\
\text { Bleached }\end{array}$ & $\begin{array}{c}\text { O(DC)(EOP)DP } \\
\text { Bleached }\end{array}$ & $\begin{array}{c}\text { OD(EOP)DD } \\
\text { Bleached }\end{array}$ & $\begin{array}{c}\text { OD(EOP)DP } \\
\text { Bleached }\end{array}$ \\
\hline 1 & 2,81 & 1,72 & 3,27 & 1,52 \\
2 & 2,49 & 1,65 & 3,05 & 1,77 \\
3 & 2,87 & 1,72 & 3,2 & 1,84 \\
4 & 2,82 & 1,46 & 2,83 & 1,59 \\
5 & 2,88 & 1,6 & 3,02 & 1,54 \\
6 & 2,8 & 1,39 & 3,08 & 2,70 \\
7 & 2,98 & 1,38 & 2,98 & 1,62 \\
8 & 3,08 & 1,48 & 3,06 & 1,86 \\
9 & 2,72 & 1,68 & 3,05 & 1,60 \\
10 & 3,05 & 1,38 & 3,02 & 1,71 \\
Average & 2,85 & 1,55 & 3,06 & 0,1672 \\
Std deviation & 0,1708 & 0,1428 & 0,1186 & 8,3 \\
\hline
\end{tabular}

*Calculated based on Gomes, (1964).

R. Árvore, Viçosa-MG, v.30, n.3, p.439-450, 2006 


\section{RESULTS AND DISCUSSION}

Preparation and drying of pulp hand sheets prior to testing may affect reversion considerably. Pulp pH and moisture content are very important factors. Market pulp producers tend to control $\mathrm{pH}$ from 4.5-6.0 at the end of bleaching and dry the pulp to $88-90 \%$ solids, i.e., $12-10 \%$ moisture content for many reasons other than reversion control. Pulp metals reduction with $\mathrm{SO}_{2}$ in the absence of chelants is also common practice in the industry. Reduction in the presence of chelants has proven effective but is usually not practiced because of its high cost.

The results in Table 3 show the impact of pulp $\mathrm{pH}$ on reversion of a $\mathrm{O}(\mathrm{ZE}) \mathrm{D}(\mathrm{PO})$ bleached pulp. In all cases pulp $\mathrm{pH}$ was adjusted with $\mathrm{SO}_{2}$ to the desired value after bleaching and pulp hand sheets were dried to $91 \pm 0.5 \%$. It is clear that minimum reversion was obtained at $\mathrm{pH}$ values in the range of 6.0-7.0, in agreement with previous work(GELLERSTEDT andPETTERSSON, 1977).
The results in Table 4 show the impact of pulp dryness on reversion. In all cases pulp $\mathrm{pH}$ was adjusted to 6.0 with $\mathrm{SO}_{2}$. Different degrees of pulp dryness were obtained by acclimating Tappi hand sheets for 12 hours in a conditioned room with adjustable temperature and humidity. The results indicate that reversion decreases as dryness increases. This trend has also been found by other researches and explained on the basis of water's participation in the diffusion of reactive species that contribute to reversion reactions (GRANSTRÖM et al., 2001).

Impact of wood supply, pulping and bleaching process on reversion. The most important information gathered in this study is summarized in Table 6, including average data on pulping, oxygen delignification, bleaching, brightness reversion, and pulp chemical characteristics. In the subsequent sections attempt is made to determine correlations between brightness reversion and the various process and pulp chemistry parameters listed in Table 6 .

Table 6 - Average results of pulping, oxygen delignification, bleaching, brightness reversion and chemistry of eucalyptus pulp samples derived from 13 different eucalyptus wood clones

Tabela 6 - Média dos resultados da polpação, deslignificação com oxigênio (Pré-O), branqueamento e reversão de alvura dos 13 diferentes clones de eucalipto

\begin{tabular}{|c|c|c|c|c|c|c|c|c|c|c|c|c|c|}
\hline \multirow[t]{2}{*}{ Results } & \multicolumn{13}{|c|}{ Pulp samples from 13 Eucalyptus Clones } \\
\hline & 1 & 2 & 3 & 4 & 5 & 6 & 7 & 8 & 9 & 10 & 11 & 12 & 13 \\
\hline Wood density, $\mathrm{kg} / \mathrm{m}^{3}$ & 468 & 452 & 428 & 503 & 481 & 491 & 525 & 520 & 451 & 462 & 445 & 518 & 400 \\
\hline Effective alkali, \% $\mathrm{NaOH}$ & 14.1 & 14.6 & 15.5 & 15.7 & 14.7 & 16.6 & 14.6 & 16 & 15.7 & 14.6 & 15.2 & 15.2 & 15.5 \\
\hline Pulping yield, \% & 54.6 & 54.5 & 54.3 & 54.2 & 54.2 & 53.9 & 53.8 & 53.8 & 53.8 & 53.6 & 53.5 & 53.3 & 52.9 \\
\hline Kappa \# after pulping & 15.8 & 16.9 & 15.1 & 15.0 & 16.3 & 15.2 & 17.4 & 14.9 & 17.0 & 16.2 & 16.4 & 16.0 & 17.4 \\
\hline Brightness after pulping, $\%$ ISO & 37.7 & 39.2 & 36.4 & 35.1 & 34.6 & 33.9 & 31.2 & 36.4 & 34.0 & 38.6 & 35.9 & 34.5 & 36.6 \\
\hline Viscosity after pulping, $\mathrm{cP}$ & 56.6 & 47.9 & 39.4 & 43.9 & 46.3 & 40.0 & 47.3 & 42.0 & 48.2 & 53.9 & 47.1 & 62.9 & 67.7 \\
\hline HexA's after pulping, $\mathrm{mmol} / \mathrm{kg}$ & 40.4 & 44.6 & 46.1 & 41.5 & 40.5 & 43.2 & 34.8 & 43.4 & 40.7 & 44.0 & 41.1 & 43.7 & 43.3 \\
\hline $\mathrm{Ca}, \mathrm{mg} / \mathrm{kg}$ & 3076 & 2901 & 2987 & 2777 & 3120 & 2893 & 2750 & 2726 & 3050 & 2961 & 3140 & 2965 & 3143 \\
\hline $\mathrm{Mg}, \mathrm{mg} / \mathrm{kg}$ & 488 & 443 & 444 & 440 & 516 & 421 & 486 & 464 & 483 & 464 & 524 & 479 & 468 \\
\hline $\mathrm{Fe}, \mathrm{mg} / \mathrm{kg}$ & 194 & 346 & 215 & 84 & 204 & 146 & 133 & 120 & 170 & 201 & 309 & 225 & 209 \\
\hline $\mathrm{Mn}, \mathrm{mg} / \mathrm{kg}$ & 7.4 & 14.2 & 17.9 & 5.6 & 6.3 & 5.2 & 7.6 & 6.5 & 6.3 & 10.1 & 22.7 & 11.6 & 11.5 \\
\hline $\mathrm{Cu}, \mathrm{mg} / \mathrm{kg}$ & 3.3 & 4.3 & 2.7 & 1.6 & 2.6 & 2.0 & 2.3 & 3.2 & 2.7 & 2.8 & 1.9 & 2.0 & 3.2 \\
\hline Kappa \# after O-stage & 11.6 & 10.0 & 11.7 & 9.4 & 11.2 & 10.2 & 10.8 & 9.5 & 11.5 & 11.5 & 11.5 & 11.3 & 10.4 \\
\hline Brightness after O-stage, $\%$ ISO & 47.5 & 48.7 & 46.5 & 50.6 & 44.9 & 45.6 & 43.3 & 50.1 & 45.0 & 45.7 & 43.6 & 43.4 & 47.2 \\
\hline Viscosity after O-stage, $\mathrm{mPa} . \mathrm{s}$ & 41.7 & 23.9 & 31.9 & 28.9 & 37.6 & 28.5 & 29.8 & 25.8 & 33.5 & 30.8 & 37.3 & 34.9 & 25.0 \\
\hline$\Delta$ Kappa across O-stage, $\%$ & 26.6 & 40.8 & 22.5 & 37.3 & 31.3 & 32.9 & 37.9 & 36.2 & 32.4 & 29.0 & 29.9 & 29.4 & 40.2 \\
\hline $\begin{array}{l}\Delta \text { Kappa across O-stage, } \\
\text { kappa unit }\end{array}$ & 4.2 & 6.9 & 3.4 & 5.6 & 5.1 & 5.0 & 6.6 & 5.4 & 5.5 & 4.7 & 4.9 & 4.7 & 7.0 \\
\hline$\Delta$ brightness across $\mathrm{O}$-stage, $\%$ & 20.6 & 19.5 & 21.7 & 30.6 & 22.9 & 25.7 & 27.9 & 27.3 & 24.4 & 15.5 & 17.7 & 20.5 & 22.5 \\
\hline$\Delta$ Viscosity across O-stage, $\%$ & 26.3 & 50.1 & 19.0 & 34.2 & 18.8 & 28.8 & 37.0 & 38.6 & 30.5 & 42.9 & 20.8 & 44.5 & 63.1 \\
\hline$\Delta$ Viscosity across $\mathrm{O}$-stage, $\mathrm{cP}$ & 14.9 & 24.0 & 7.5 & 15.0 & 8.7 & 11.5 & 17.5 & 16.2 & 14.7 & 23.1 & 9.8 & 28.0 & 42.7 \\
\hline Selectivity, cP & 3.5 & 3.5 & 2.2 & 2.7 & 1.7 & 2.3 & 2.7 & 3.0 & 2.7 & 4.9 & 2.0 & 6.0 & 6.1 \\
\hline Kappa \# ODE & 3.2 & 3.8 & 3.9 & 3.6 & 3.8 & 3.5 & 2.8 & 4.0 & 3.6 & 3.3 & 3.7 & 3.9 & 3.5 \\
\hline
\end{tabular}




\begin{tabular}{|c|c|c|c|c|c|c|c|c|c|c|c|c|c|}
\hline \multirow[t]{2}{*}{ Results } & \multicolumn{13}{|c|}{ Pulp samples from 13 Eucalyptus Clones } \\
\hline & 1 & 2 & 3 & 4 & 5 & 6 & 7 & 8 & 9 & 10 & 11 & 12 & $\overline{13}$ \\
\hline Brightness ODE, \% ISO & 73.7 & 75.8 & 76.7 & 75.4 & 72.2 & 72.6 & 72.0 & 74.2 & 72.2 & 73.7 & 70.8 & 71.5 & 74.2 \\
\hline Viscosity ODE, mPa.s & 29.6 & 22.2 & 27.1 & 23.6 & 30.8 & 26.1 & 22.6 & 22.5 & 30.3 & 24.0 & 31.6 & 29.4 & 21.8 \\
\hline Brightness ODED, \% ISO & 87.3 & 87.7 & 88.0 & 88.1 & 89.0 & 87.5 & 87.5 & 88.5 & 87.8 & 88.2 & 86.8 & 87.0 & 88.1 \\
\hline Brightness ODEDD, \% ISO & 90.5 & 90.2 & 90.2 & 90.8 & 90.6 & 90.1 & 90.0 & 90.7 & 90.5 & 90.8 & 90.2 & 89.9 & 90.5 \\
\hline $\begin{array}{l}\text { Brightness ODEDD } \\
\text { after Rev., \% ISO }\end{array}$ & 86.9 & 86.9 & 87.4 & 88.6 & 87.9 & 87.0 & 86.8 & 88.4 & 88.3 & 88.1 & 87.4 & 87.8 & 88.0 \\
\hline$\Delta \mathrm{R}_{457}, \%$ ISO & 3.6 & 3.3 & 2.8 & 2.2 & 2.7 & 3.1 & 3.2 & 2.3 & 2.2 & 2.7 & 2.8 & 2.1 & 2.5 \\
\hline Post color number $(\mathrm{PCN})$ & 0.49 & 0.46 & 0.38 & 0.27 & 0.35 & 0.43 & 0.45 & 0.28 & 0.28 & 0.34 & 0.38 & 0.28 & 0.32 \\
\hline$\Delta \mathrm{b}^{*}$ Coordinate & 2.57 & 2.51 & 2.17 & 1.44 & 2.05 & 2.54 & 2.57 & 1.85 & 1.88 & 2.22 & 2.15 & 1.70 & 1.66 \\
\hline Total Act. $\mathrm{Cl}_{2}$ requirement, $\%$ & 4.72 & 4.40 & 4.74 & 4.28 & 4.44 & 4.44 & 4.56 & 4.10 & 4.70 & 4.70 & 4.70 & 4.66 & 4.48 \\
\hline $\begin{array}{l}\text { Bleach ability } \\
\left(\mathrm{K} \text { units } \% \text { act } \mathrm{Cl}_{2}\right)\end{array}$ & 2.46 & 2.27 & 2.47 & 2.20 & 2.52 & 2.30 & 2.37 & 2.32 & 2.45 & 2.45 & 2.45 & 2.42 & 2.32 \\
\hline Carboxyl groups, meq/100g & 7.05 & 6.08 & 6.01 & 5.19 & 6.76 & 6.47 & 6.69 & 5.84 & 5.31 & 5.57 & 5.15 & 4.75 & 5.67 \\
\hline Carbonyl groups, $\mathrm{gCu}_{2} \mathrm{O} / 100 \mathrm{~g}$ & 0.40 & 0.34 & 0.32 & 0.27 & 0.30 & 0.31 & 0.30 & 0.29 & 0.24 & 0.30 & 0.32 & 0.26 & 0.26 \\
\hline Hexenuronic acids, $\mathrm{mmol} / \mathrm{kg}$ & 0.15 & 0.18 & 0.17 & 0.17 & 0.15 & 0.14 & 0.14 & 0.31 & 0.19 & 0.19 & 0.21 & 0.27 & 0.33 \\
\hline Permanganate number & 0.90 & 0.90 & 0.80 & 0.40 & 0.90 & 1.00 & 0.90 & 0.60 & 0.40 & 0.50 & 0.70 & 0.60 & 0.50 \\
\hline Acid Soluble lignin, $\%$ & 0.15 & 0.15 & 0.13 & 0.07 & 0.16 & 0.18 & 0.14 & 0.10 & 0.06 & 0.08 & 0.12 & 0.09 & 0.09 \\
\hline Dichloromethane extractibles, $\%$ & 0.18 & 0.16 & 0.29 & 0.36 & 0.20 & 0.15 & 0.10 & 0.46 & 0.22 & 0.18 & 0.35 & 0.45 & 0.31 \\
\hline Viscosity ODEDD, cP & 17.6 & 12.2 & 14.6 & 13.0 & 14.8 & 12.9 & 15.1 & 17.0 & 21.4 & 18.2 & 22.5 & 20.3 & 17.5 \\
\hline Brightness ODEDP, \% ISO & 90.9 & 90.9 & 90.9 & 90.5 & 90.8 & 90.8 & 90.7 & 90.7 & 90.5 & 90.7 & 90.1 & 90.0 & 90.6 \\
\hline Bright. ODEDP after rev, \% ISO & 89.2 & 89.6 & 89.9 & 89.7 & 89.6 & 89.2 & 89.0 & 89.4 & 89.2 & 89.5 & 88.8 & 89.0 & 89.3 \\
\hline $\begin{array}{l}\Delta \mathrm{R}_{457}, \% \text { ISO } \\
\text { Post color number (PCN) }\end{array}$ & $\begin{array}{c}1.7 \\
0.20\end{array}$ & $\begin{array}{c}1.3 \\
0.15\end{array}$ & $\begin{array}{c}1.0 \\
0.11\end{array}$ & $\begin{array}{c}0.8 \\
0.09\end{array}$ & $\begin{array}{c}1.2 \\
0.14\end{array}$ & $\begin{array}{c}1.6 \\
0.19\end{array}$ & $\begin{array}{c}1.7 \\
0.20\end{array}$ & $\begin{array}{c}1.3 \\
0.15\end{array}$ & $\begin{array}{c}1.3 \\
0.16\end{array}$ & $\begin{array}{c}1.2 \\
0.14\end{array}$ & $\begin{array}{c}1.3 \\
0.16\end{array}$ & $\begin{array}{c}1.0 \\
0.12\end{array}$ & $\begin{array}{c}1.3 \\
0.15\end{array}$ \\
\hline$\ddot{\mathrm{A}} \mathrm{b} *$ coordinate & 1.15 & 1.08 & 0.88 & 0.92 & 1.02 & 1.18 & 1.08 & 1.09 & 1.09 & 1.03 & 1.11 & 0.88 & 1.07 \\
\hline Total Act. $\mathrm{Cl}_{2}$ requirement, $\%$ & 5.16 & 4.84 & 4.76 & 4.22 & 4.86 & 4.88 & 5.00 & 4.32 & 4.72 & 4.92 & 5.14 & 4.68 & 4.50 \\
\hline Bleach ability, $\mathrm{K}$ units/ $\%$ act $\mathrm{Cl}_{2}$ & 2.25 & 2.07 & 2.46 & 2.23 & 2.30 & 2.09 & 2.16 & 2.20 & 2.44 & 2.34 & 2.24 & 2.41 & 2.31 \\
\hline Carboxyl groups, meq/100g & 8.35 & 7.24 & 7.21 & 6.03 & 8.04 & 7.69 & 8.15 & 7.04 & 6.38 & 6.62 & 6.64 & 6.14 & 6.74 \\
\hline Carbonyl groups, $\mathrm{gCu}_{2} \mathrm{O} / 100 \mathrm{~g}$ & 0.24 & 0.23 & 0.22 & 0.21 & 0.2 & 0.21 & 0.19 & 0.17 & 0.15 & 0.19 & 0.18 & 0.17 & 0.15 \\
\hline Hexenuronic acids, $\mathrm{mmol} / \mathrm{kg}$ & 0.15 & 0.32 & 0.31 & 0.4 & 0.2 & 0.38 & 0.22 & 1.21 & 0.56 & 0.64 & 0.78 & 1.03 & 1.23 \\
\hline Permanganate number & 1 & 0.8 & 0.4 & 0.5 & 0.6 & 1.2 & 0.6 & 0.5 & 0.6 & 0.4 & 0.6 & 0.4 & 0.6 \\
\hline Acid soluble lignin, $\%$ & 0.2 & 0.15 & 0.07 & 0.08 & 0.1 & 0.22 & 0.11 & 0.09 & 0.12 & 0.05 & 0.11 & 0.07 & 0.13 \\
\hline Dichloromethane extractibl & 0.23 & 0.2 & 0.24 & 0.3 & 0.26 & 0.18 & 0.14 & 0.54 & 0.23 & 0.22 & 0.31 & 0.39 & 0.28 \\
\hline Viscosity ODEDP, cP & 15.6 & 9.6 & 12.8 & 12.2 & 17.7 & 12.8 & 13.3 & 14.7 & 19.3 & 13.8 & 17.2 & 17.9 & 15.7 \\
\hline
\end{tabular}

Effect of wood supply and density. Figure 3 shows the impact of different eucalyptus wood types on brightness reversion of ODEDD and ODEDP laboratory bleached kraft pulps. Note that all 13 wood samples originated from 5.5 year old Eucalyptus grandis $x$ Eucalyptus urophylla clones. Brightness reversion, measured by the $\Delta \mathrm{R}_{457}$ values varies significantly among the various woods, regardless of the bleaching sequence. Variations in the range of 2.1-3.6\% ISO were observed for the ODEDD bleached pulps while smaller variations (0.8-1.7 \% ISO) were seen for the ODEDP bleached pulps (Table 6). Since pulping and bleaching of the various woods were carried out under similar conditions, except for the chemical charges used, it is anticipated that some of the brightness reversion variations can be traced to the wood nature itself. Among the wood components that may have caused the differences in brightness stability among the various pulps are their hexenuronic acids, lignin, extractives, and metals contents. The impact of these chemical characteristics is thoroughly discussed in the following sections. Wood density, which is one of the main wood quality control parameters in pulp mills seems to have very little or no correlation with pulp brightness reversion even though this wood trait varied significantly, from 400 to $535 \mathrm{~kg} / \mathrm{m}^{3}$ (Table 6).

Effect of pulping. Effective alkali requirement and pulp yield showed little correlation with brightness reversion, regardless of bleaching sequence (Figures 4 and 5). There was a slight tendency of decreased reversion with increasing cooking effective alkali in 
the range from 14.1 to $16.6 \%$, particularly for the pulp bleached with the ODEDD sequence (Figure 4). This may be explained by more severe removal of pulp xylans that purportedly hold most of the uronic acids present in bleached hardwood kraft pulps. The impact of cooking effective alkali on minimization of kraft pulp xylan and hexenuronic acid contents has been documented in the scientific literature (COLODETTE et al. 2001). Furthermore, there is a slight positive correlation between pulping yield, in the range from 52.9 to $54.6 \%$, and brightness reversion (Figure 5). This may also be explained by retention of larger amounts of xylans in higher yield pulps. Kappa number varied in the range from 14.9-17.4 (Table 6). The target was a kappa number between 16 and 17, which is typical for eucalyptus kraft pulps, but this fine-tuning was difficult to achieve given the large number of samples cooked (one hundred).

Effect of oxygen delignification. No significant influence of O-stage efficiency, brightening or selectivity on pulp brightness reversion was observed (Figures 6,7 and 8). Certain oxygen-derived free radicals can be created in the $\mathrm{O}$-stage, which may give rise to cellulose oxidation and formation of carboxyl groups in the pulp. Hence, it was anticipated that a very efficient O-stage could enhance brightness reversion. However, Figure 6 shows delignification efficiencies ranging from 22$41 \%$ with no apparent correlation with brightness reversion. The variation in $\mathrm{O}$-stage efficiency was solely caused by differences in the wood type since O-stage conditions were kept constant. Similarly, the brightness gain (Figure 7) obtained in the O-stage, which correlates well with efficiency, had no significant correlation with

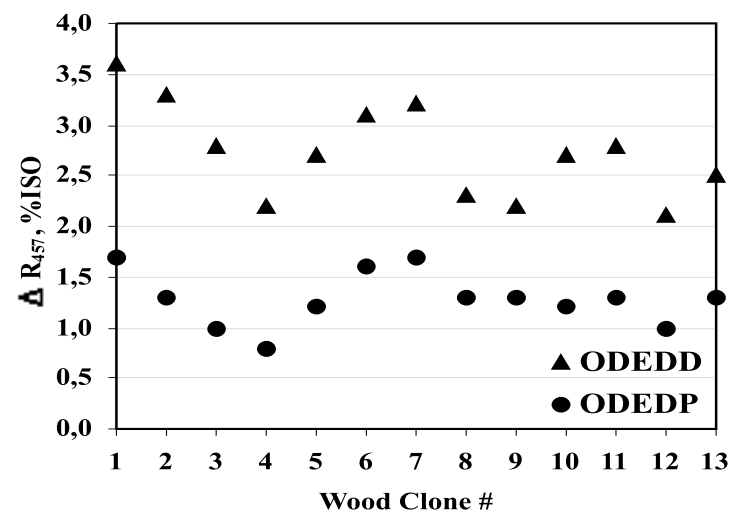

Figure 3 - Wood clone x brightness reversion. Figura 3 - Clones $x$ reversão de alvura. brightness reversion although it varied from 15.5 to $30.6 \%$ ISO. O-stage selectivity varied from 1.7 to 6.1 , indicating significant differences in carbohydrate attack in the process, but showed no correlation with heat reversion either (Figure 8 ).

ECF Bleaching. The thirteen pulp samples bleached to $90-91 \%$ ISO brightness with the sequences ODEDD and ODEDP presented only slight differences in chemical consumption and bleachability. The total active chlorine requirement varied in the range $4.10-4.72 \%$ and 4.22 $5.16 \%$ (Figure 9), whereas bleachability varied in the range of 2.20-2.47 and 2.07-2.46 kappa unit/\% act. $\mathrm{Cl}_{2}$ for the ODEDD and ODEDP sequences, respectively (Table 6). Although no significant correlation was found, there seems to be a slight trend for increased brightness reversion with increasing bleaching chemical consumption for the ODEDP sequence. Note that variations in chemical consumption and bleachability within the samples studied were not sufficiently large to make good inferences.

It is worth noting, however, that the ODEDP bleached pulp showed brightness reversion 1.3-1.9\% ISO units lower than the ODEDD bleached pulp. This difference is very significant considering that the chemical requirement and bleachability of the two sequences were similar. The difference is obviously caused by the final peroxide bleaching stage. What peroxide does to the pulp chemistry in the final stage to prevent reversion is still unclear. The alkaline condition used in the final $\mathrm{P}$ stage, in contrast to the acid conditions used in de $\mathrm{D}_{2}$ stage, is certainly the reason why the former decreases reversion.

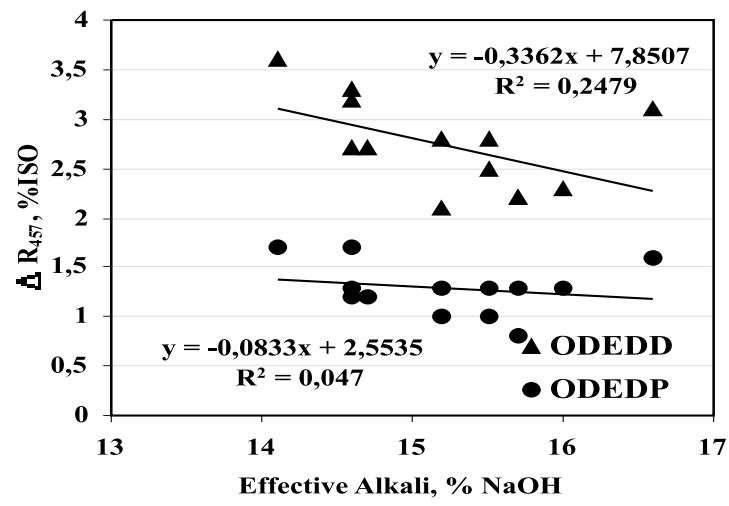

Figure 4 - Cooking effective alkali $x$ brightness reversion. Figura 4 - Álcali efetivo do cozimento x reversão.

R. Árvore, Viçosa-MG, v.30, n.3, p.439-450, 2006 


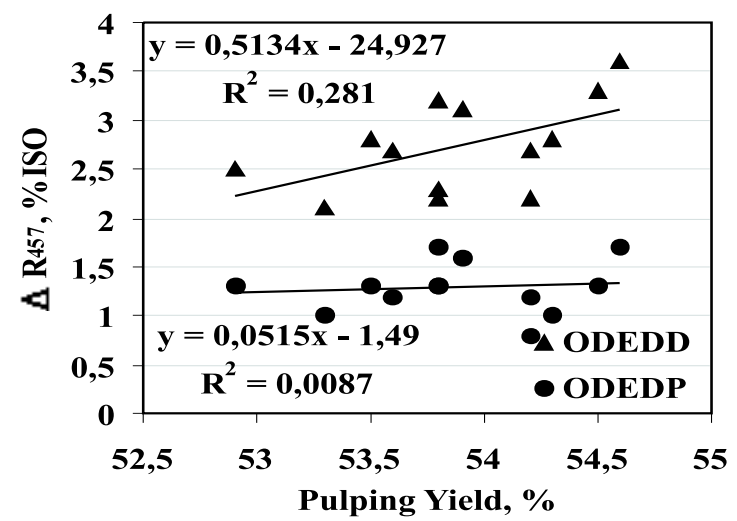

Figure 5 - Cooking yield $\mathrm{x}$ brightness reversion. Figura 5 - Rendimento da polpação x reversão de alvura.

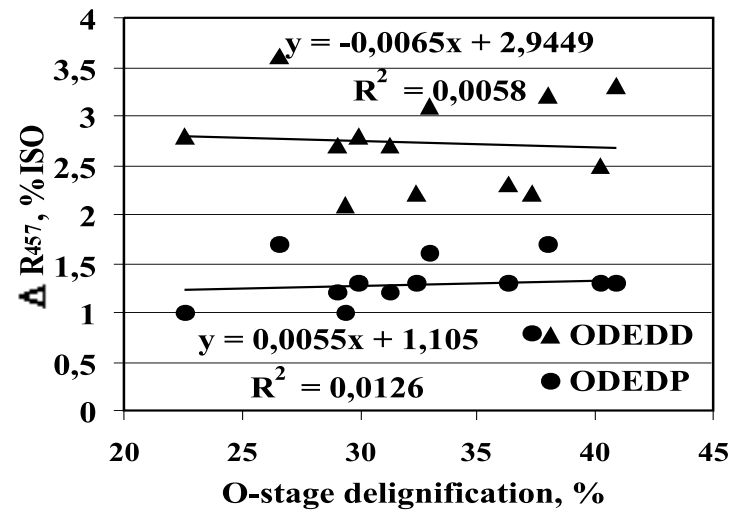

Figure 6 - O-stage efficiency x brightness reversion. Figura 6-Eficiência no estágio pré-O x reversão de alvura.

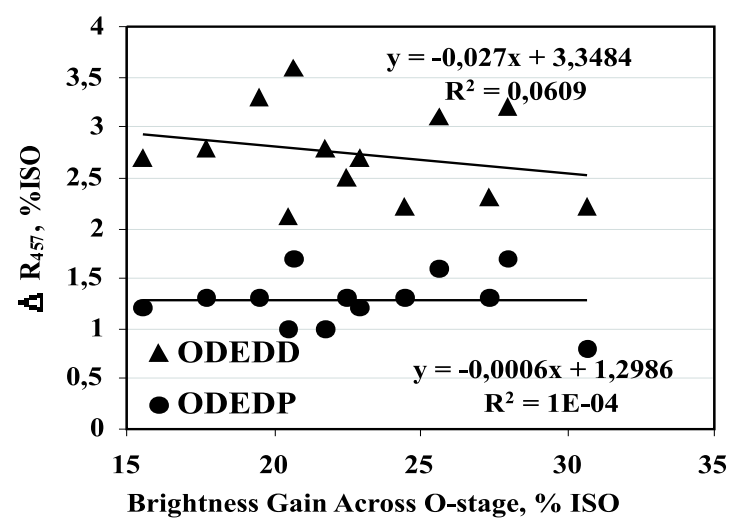

Figure 7 - O-stage brightness gain $\mathrm{x}$ brightness reversion. Figura 7-Ganho de alvura no estágio pré-O x reversão de alvura.

R. Árvore, Viçosa-MG, v.30, n.3, p.439-450, 2006

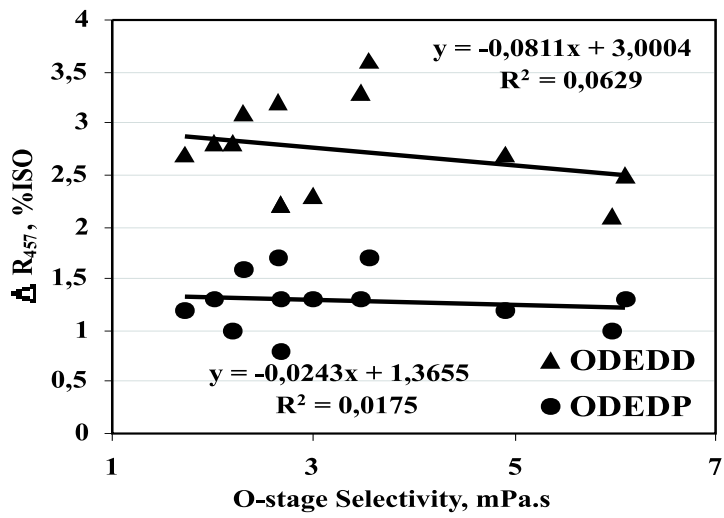

Figure 8 - O-stage selectivy x brightness reversion.

Figura 8 -Seletividade no estágio pré-O x reversão de alvura.

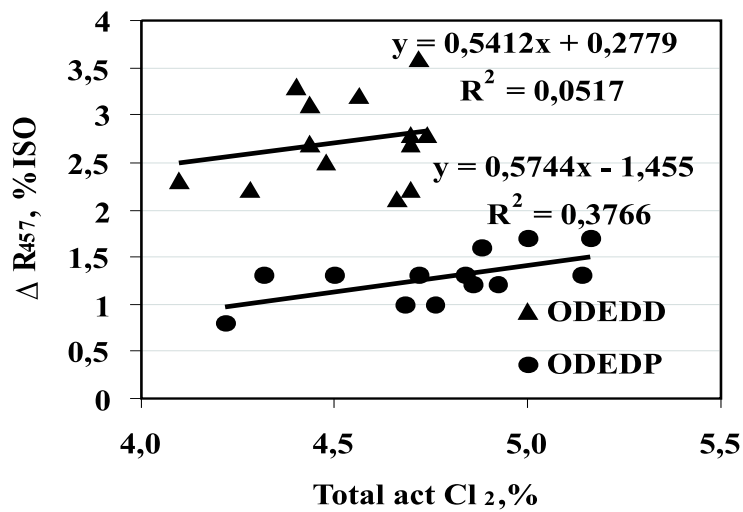

Figura 9 - Bleaching chemical consumption $\mathrm{x}$ brightness reversion.

Figura 9-Consumo de químicos no branqueamento x reversão de alvura.

There have been speculations that thermally harmful substances present in the pulp are solubilized under alkaline conditions (FORSSKÅHL, 2000). Such substances may not be soluble under the acidic conditions existing in the final D stage. Others have speculated that hydrogen peroxide is able to react with carbonyl groups and minimize their effect on reversion (LACHENAL and NGUYEN-THI, 1993; ANDERSON and AMINI, 1996).

Pulp Chemistry. The hexenuronic acid (HexA's) content varied in the range of 34.8-44.6 $\mathrm{mmol} / \mathrm{kg}$ for the brown pulp, and $0.14-0.33$ and $0.15-1.23 \mathrm{mmol} / \mathrm{kg}$, respectively, for the ODEDD and ODEDP bleached samples (Table 6). No positive correlations were obtained between brightness reversion and brown or bleached pulp HexA's content (Figures 10 and 11). Overall, the 
HexA's content of most bleached pulp samples were rather small to allow for any conclusion. Most literature claims that HexA's enhance pulp brightness reversion (VUORINEN et al. 1996; BUCHERT et al. 1997).

Final pulp viscosity varied in the range of 12.2-22.5 and 9.6-19.3 mPa.s for the ODEDD and ODEDP bleached pulps, respectively. Note that the brown pulp viscosity variation was in the range of 39.4-67.7 mPa.s (Table 6). Although there was significant viscosity loss across the bleaching operation and large variation among the various samples, no good correlation was found between bleached pulp viscosity and brightness reversion (Figure 12). Also, no correlation was found between brightness reversion and brown or oxygen delignified pulp viscosities (figures not shown). There was certainly a variable degree of carbohydrate degradation across cooking and bleaching among the various samples, but that did not seem to affect reversion. In principle, viscosity losses across cooking are not bound to affect reversion since degradation occurs mostly hydrolytically and do not cause carbohydrate oxidation. However, the variable degree of viscosity loss across bleaching was expected to have an effect on reversion since bleaching reactions degrade carbohydrates oxidatively.

Carboxyl groups showed reasonably good correlation with brightness reversion for both ODEDD and ODEDP bleached pulps (Figure 13), in agreement with the specialized literature (SJÖSTRÖM, 1968, CHIRAT, 1999; TRAN, 2002). In fact it has been demonstrated that that carboxyl groups at $\mathrm{C}_{1}$ and/or $\mathrm{C}_{6}$ in cellulose are more detrimental to heat reversion than carboxyl groups at $\mathrm{C}_{2}$ and $\mathrm{C}_{3}$ (CHIRAT, 1999).

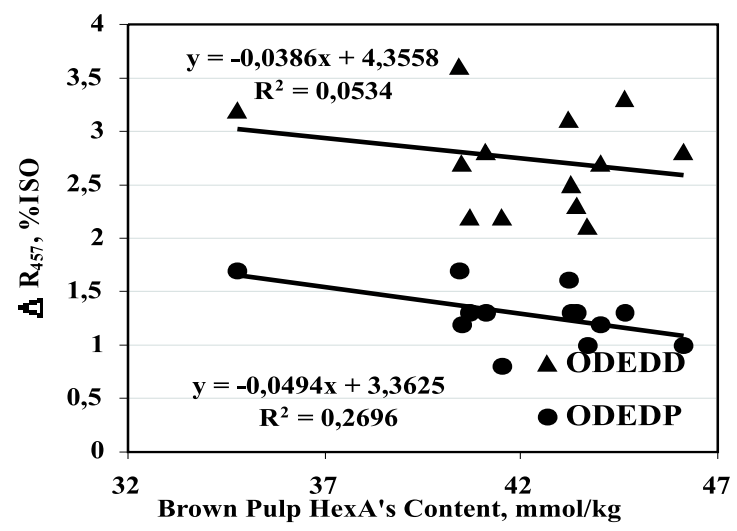

Figure 10 - Brown pulp HexA's x brightness reversion. Figura 10 - Conteúdo de HexA's na polpa marrom x reversão de alvura.

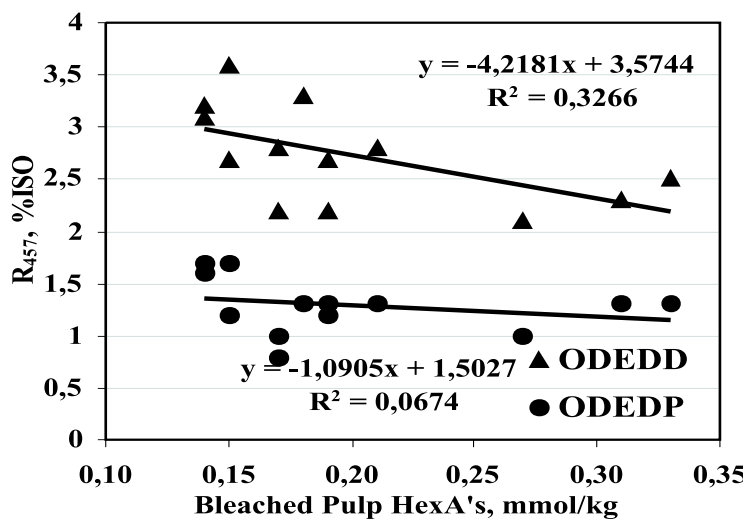

Figure 11 - Bleached pulp Hex's x brightness reversion. Figura 11 - Conteúdo de HexA's na polpa branqueada $x$ reversão de alvura.

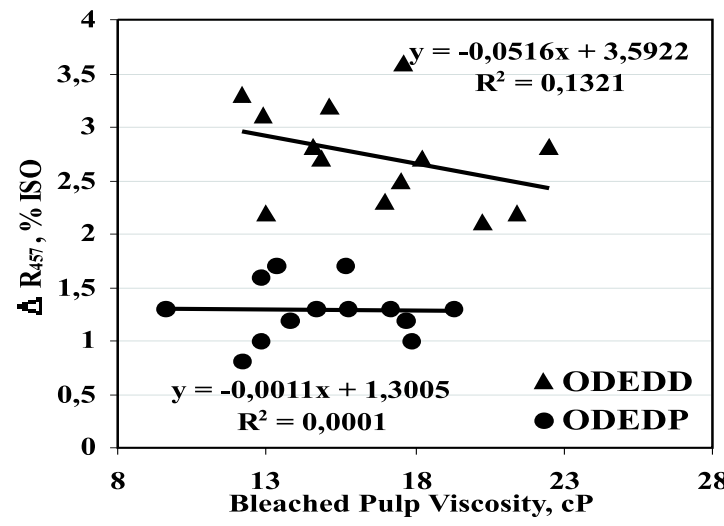

Figure 12 - Bleached pulp viscosity $\mathrm{x}$ brightness reversion. Figura 12 - Viscosidade da polpa branqueada x reversão de alvura.

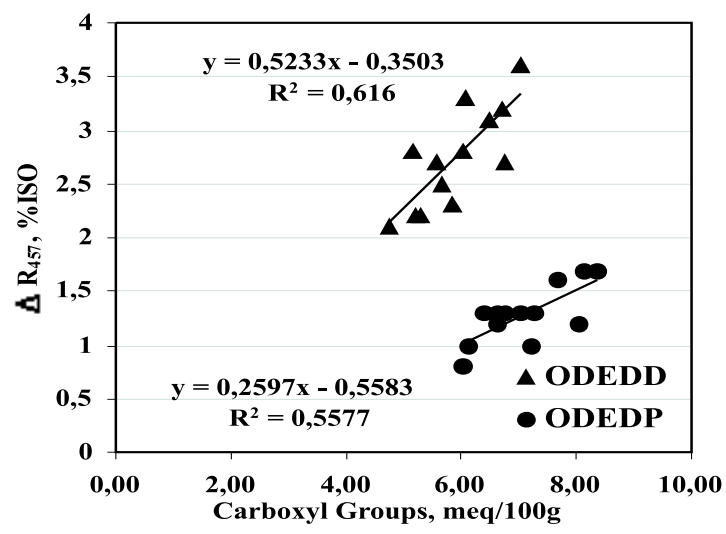

Figura 13 - Carboxyl group content $x$ brightness reversion. Figura 13 - Conteúdo de grupos carboxila x reversão de alvura.

R. Árvore, Viçosa-MG, v.30, n.3, p.439-450, 2006 
Carbonyl groups also correlated reasonably well with brightness reversion in the ODEDD bleached pulps, but not in the ODEDP bleached pulps (Figure 14). The alkaline/oxidative conditions existing in the final peroxide stage destroyed a significant fraction of the pulp carbonyl groups (35-40\%). Since the level of carbonyl removal in the final P-stage was somewhat similar among the various pulps, it was expected that the positive correlation should have been maintained in the ODEDP sequence. There may be a threshold carbonyl concentration below which heat reversion is no longer affected, and this limiting number may have been reached after the final P-stage. Also, reaching 90-91\% ISO brightness required different peroxide doses for different pulps in the final $P$ stage, which may have affected the level of reversion in the various pulps. The negative impact of carbonyl groups on reversion is well documented in the literature (RAPSON 1957; SJÖSTRÖM, 1968; RAPSON, 1979; LACHENAL and NGUYEN-THI, 1993; TRAN, 2000).

Figures 15 and 16 indicate reasonably good correlation between brightness reversion and permanganate number or acid insoluble lignin. Permanganate number varied in the range of 0.40-10 and 0.4-1.2 for the samples bleached with the ODEDD and ODEDP sequences. Although these numbers are small, they seem to have impacted brightness reversion significantly. It is worth noting that permanganate or kappa number are no longer accepted as good techniques to quantify pulp residual lignin since they do not separate lignin from hexenuronic acids (VUORINEN, 1996). However, the residual acid soluble lignin also gave good correlation with brightness reversion. In this particular study, permanganate number and acid soluble lignin showed good correlation between them since the amounts of hexenuronic acids left in the bleached pulps were rather small (Table 6). Lignin is well known to cause pulp brightness reversion in mechanical, chemimechanical and totally chlorine free and chlorinescarce bleached pulps (FORSSKÅHL, 2000). Pulps bleached to $90-91 \%$ brightness with sequences such as ODEDD and ODEDP are not expected to contain significant amounts of lignin considering the various electrophylic oxidative steps they go through, but this was not the case for the samples studied.

Surprisingly, there were slight negative correlations between dichloromethane extractibles and brightness reversion, particularly for the ODEDD bleached eucalyptus pulps (Figure 17). Although the $\mathrm{R}^{2}$ value is only $53 \%$, this matter needs further investigation for eucalyptus pulps given the fact that there is a vast literature indicating the opposite trend for various wood pulps as reported by Forsskåhl, 2000.

Iron $\left(\mathrm{Fe}^{2+}\right.$ and $\left.\mathrm{Fe}^{3+}\right)$ and copper have been considered the most harmful inorganic wood components for pulp brightness stability (JANSON e FORSSKÅHL, 1989). Figure 18 shows little correlation between pulp iron content and reversion. This was also the case for other metals such as $\mathrm{Cu}, \mathrm{Mn}, \mathrm{Ca}$ and Mg (Table 6). Most studies indicating a negative impact of metals, particularly iron, on reversion have been done on mechanical pulps, which contain rather high contents of these metals (GUPTA, 1970; JANSON e FORSSKÅHL, 1989). A significant part of the metals are removed during the various acid stages the pulp goes through during chemical pulp bleaching and their effect on reversion become less significant.

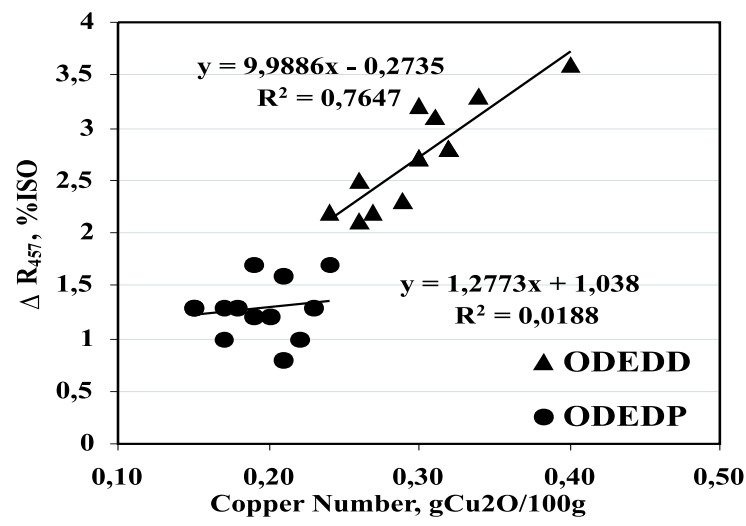

Figure 14 - Carbonyl group content $\mathrm{x}$ brightness reversion. Figura 14 - Conteúdo de grupos carbonila x reversão de alvura.

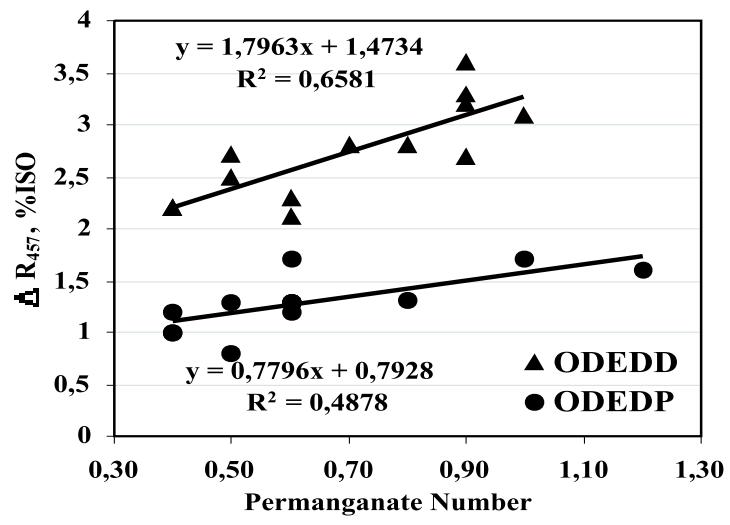

Figure 15 - Permanganate number $\mathrm{x}$ brightness reversion. Figura 15 - Número de permanganato x reversão de alvura. 


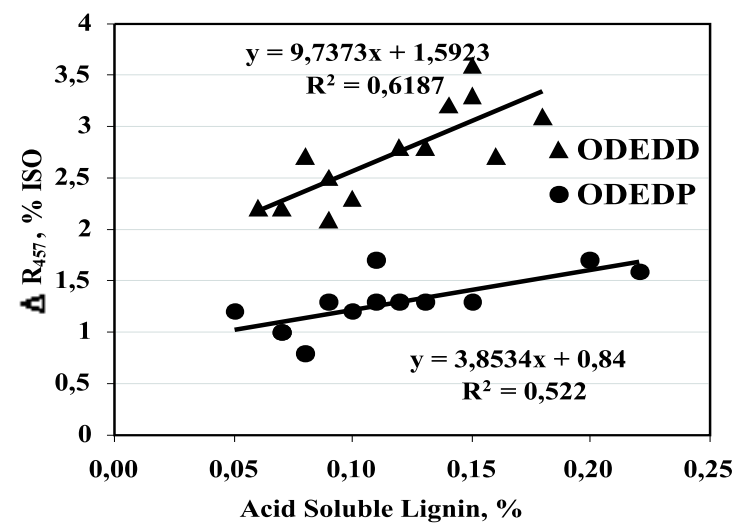

Figure 16 - Acid soluble lignin $\mathrm{x}$ brightness reversion. Figura 16-Lignina solúvel em ácido x reversão de alvura.

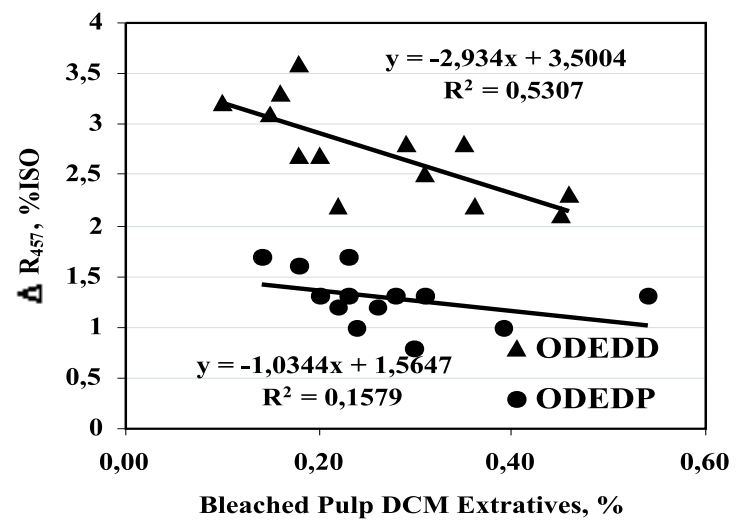

Figure 17 - DCM estractives $\mathrm{x}$ brightness reversion. Figura 17 - Extrativos DCM x reversão de alvura.

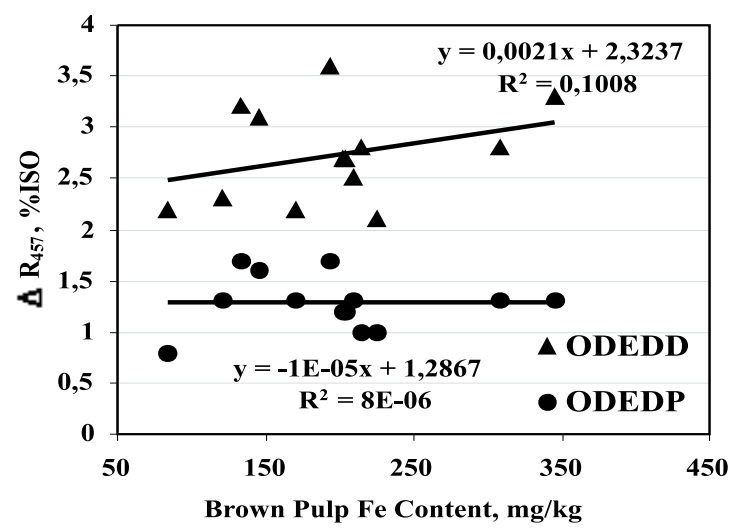

Figura 18 - Brown pulp iron content $\mathrm{x}$ brightness reversion. Figura 18 - Conteúdo de ferro na polpa marrom x reversão de alvura.

\section{CONCLUSION}

The type of eucalyptus wood has a very significant effect on brightness stability of fully bleached pulp, independently of pulping and bleaching processes. In general, heat reversion correlates positively with bleached pulp carbonyl, carboxyl, acid soluble lignin and permanganate number and is not affected by metals and DCM extractive contents. Control of wood supply and pulp manufacturing process in order to minimize heat reversion is difficult given the problem complexity and the various factors affecting it. Processes and conditions aimed at total lignin removal may lead to increased pulp carboxyl groups whereas those designed to minimize carboxyl groups may lead to increased carbonyl groups and viceversa. A final peroxide bleaching stage is quite useful to improve pulp brightness stability.

\section{REFERENCES}

ANDERSON, J. R.; AMINI, B. In: DENCE, C. W.; REEVE, D.W. (Ed.). Pulp Bleaching principle and practices. Atlanta-USA: Tappi Press, 1999, p. 411-442.

BUCHERT, J. et al. Significance of xylan and glucomannan in the brightness reversion of kraft pulps. Tappi Journal, v. 80, n. 6, p. 165-170, 1997.

CHIRAT, C.; De La CHAPELLE. Heat and light induced brightness reversion of bleached chemical pulps. Journal Pulp and Paper Science, v. 25, n. 6, p. 201-205, 1999.

COLODETTE, J. L. et al. Effluence of pulping conditions on eucalyptus kraft pulp yield, quality and bleachability. Tappi Journal, v. 1, n. 1, p. 14-19, 2001.

FORSSKÅHL, I. Papermaking Science and Technology. In: GULLICHSEN, J.; PAULAPURO, H. (Ed). Atlanta-USA: Tappi Press, 2000. p. 277-350.

GRANSTROM, A. et al. Variables affecting the thermal yellowing of TCF-Bleached birch kraft pulps. Nordic Pulp and Paper Research Journal, v. 16, p. 18-23, 2001.

GELLERSTEDT, G; PETTERSSON, E. L. LightInduced Oxidation of Lignin - Part 2: The Oxidative Degradation of Aromatic Rings. Svensk Paspperstidn, v. 80, p.15-21, 1977.

R. Árvore, Viçosa-MG, v.30, n.3, p.439-450, 2006 
GOLDSCHIMID, O. Ultraviolet spectra: In: SARKANEN, K. V.; LUDWIG, C. H. (Ed.) Lignins. New York: Wiley Interscience, 1971. p. 241-266.

GOMES, F. P. Estatística Experimental. Piracicaba: Nobel 1977. p. 29-58.

GUPTA, V. N. Effect of metal ions on brightness, bleachability and colour reversion of groundwood. Pulp and Paper Magazine of Canadian, v. 71, n. 18, p. 69-77, 1970.

HEITNER, V. Pulp Bleaching - principle andpPractices. Atlanta-USA: Tappi Press, 1996. p. 183-212.

HOLMBOM, B.; STENIUS, P. Papermaking science and technology. In: GULLICHSEN, J.; PAULAPURO, H. (Ed). Atlanta-USA: Tappi Press, 2000. p. 107-169.

JANSON, J.; FORSSKÅHL, I. Color changes in lignin-rich pulps on irradiation by light.

Nordic Pulp and Paper Research Journal. v. 4, n. 3, p. 197, 1989

LACHENAL, D.; NGUYEN-THI, N. B. Whichsequence to Choose. In: TAPPI PULPING CONFERENCE, 1993, Atlanta. Proceedings... Atlanta: Tappi, 1993. p. 799-804.
RAPSON, W. H.; HAKIN, K. A. Carbonyl groups in cellulose and color reversion. Pulp and Paper Magazine of Canadian, v. 58, n. 8, p. 151-156, 1957.

RAPSON, W. H.; SPINNER, I. H. In: The Bleaching of pulp. Atlanta-USA: Tappi Press, 1979. p. 357-391.

SJÖSTRÖM, E.; ERIKSSON, E. The influence of carboxyl and carbonyl groups on the brightness stability of bleached pulps.

Tappi Journal, v. 51, n. 1, p. 16-19, 1968.

TENKANEN, M. et al. Determination of hexenuronic acid in softwood kraft pulps by three different methods. Journal Pulp and Paper Science, v. 25, n. 9, p. 306-311, 1999.

TRAN, A. V. Thermal yellowing of hardwood kraft pulp bleached with chlorine dioxide based sequence. Journal Pulp Paper Science, v. 28 , n. 4, p. $115,2002$.

VUORINEN, T. et al. Selective hydrolysis of hexenuronic acid groups and its application in ECF and TCF bleaching of kraft pulps. In: INTERNATIONAL PULP BLEACHING CONFERENCE, Washington, 1996. Anais... Washington: Tappi, 1996. p. 43-51. 